\title{
Reminiscências Missioneiras: análise sobre a formação de Comunidades Guaranis no sul do Brasil (Capela de Santa Maria, 1804-1834)
}

\author{
Missionary recollections: Analysis of the making of the Guarani Communities \\ in the South of Brazil (Chapel of Santa Maria, 1804-1834)
}

Max Roberto Pereira Ribeiro*

Universidade do Vale do Rio dos Sinos (UNISINOS), São Leopoldo, RS, Brasil

\begin{abstract}
RESUMO: O presente artigo busca evidenciar a formação de comunidades guaranis entre os luso-brasileiros após a tomada das Missões Orientais, em 1801. Demonstra como num período ulterior à expulsão dos jesuítas (1767), os guaranis continuaram vivendo nos territórios pertencentes às Missões, organizando-se em pequenas comunidades e expressando sua religiosidade na busca do batismo católico. Analisa registros batismais de uma localidade luso-brasileira para onde se deslocaram famílias guaranis, a partir de 1804 . O texto foca nas relações de compadrio priorizando a reconstituição do grupo/comunidade através de seus laços sociais. Mostra a estrutura básica da comunidade guarani, distribuída por campos e estâncias lusobrasileiras, interligada por relações de parentesco.
\end{abstract}

PALAVRAS-CHAVE: Guaranis. Missões. Comunidades. Território. Compadrio.

\begin{abstract}
This paper intends to highlight the making of the Guarani communities among the PortugueseBrazilian after the conquest of the Eastern Missions in 1801. It is demonstrated how the Guarani, after the banishment of the Jesuits (1767), remained living in the territories that belonged to the Missions, organizing themselves in small communities and expressing their religiosity in the search for Catholicism. Baptismal records from a Brazilian community to where the Guarani were reallocated, starting in 1804, are analyzed here. The main focus is on godparenting and the reconstitution of the group/community through its social bonds is prioritized. The basic structure of the Guarani community, distributed throughtout various fields and farms PortugueseBrazilian, is shown as being interlinked by kinship.
\end{abstract}

KEYWORDS: Guarani. Missions. Territory. Godparenting.

\footnotetext{
* Doutor em História pela Universidade do Vale do Rio dos Sinos (UNISINOS). E-mail: maxrpribeiro@gmail.com. https://orcid.org/0000-0003-4661-4473.
} 


\section{Introdução}

A historiografia missioneira passou por significativas mudanças, especialmente nas últimas duas décadas, quando foi introduzida como questão fundamental a compreensão dos indígenas, alvos da ação missional. Entre as muitas características destes novos estudos há a preocupação com os indígenas após a expulsão dos padres da Companhia de Jesus das Américas. Esse período havia sido retratado por Erich Poenitz (1984), Ernesto Maeder (1992) e Julia Sarrael (2009) como o tempo da decadência dos povos missioneiros. ${ }^{1}$

Entretanto, estudos como os de Guillermo Wilde (2009), Eduardo Neumann (2015) e Leandro Fontella (2017) têm demonstrado certa longevidade das instituições missioneiras. Outras pesquisas como as de Protásio Langer (1997), Barbara Ganson (2003), Elisa Garcia (2007), Lia Quarleri (2009) e Rodrigo Maurer (2011) têm destacado situações específicas e imbricadas vividas pelas populações indígenas, mormente, a partir da segunda metade do século XVIII, em virtude do Tratado de Madrid. ${ }^{2}$

Concernente ao Brasil do século XIX, pesquisas como as de Maximiliano Menz (2001), Luís Farinatti e Max Ribeiro (2016), Karina Melo (2017), Fontella (2017) e Ribeiro (2018) têm mostrado que os guaranis das Missões seguiram rumos diversos vivenciando experiências plurais. Um estudo comparado feito a partir de registros batismais da Igreja Católica feito por Fontella e Ribeiro (2015) mostra como os guaranis remanescentes das Missões se organizaram depois da anexação pelos luso-brasileiros, em $1801 .^{3}$ A partir das relações de compadrio, o estudo torna evidente que índios e luso-brasileiros compartilhavam um mesmo espaço, porém mantinham relações sociais, em maior grau, de modo endógeno. Conforme Menz (2001) e Garcia (2009), os guaranis foram integrados à sociedade luso-brasileira que se desenvolvia. Contudo, o trabalho em questão relativiza a tese da integração mostrando que os guaranis formaram agregados de índios não integrados socialmente aos luso-brasileiros.

Estudos desta natureza têm mostrado a miríade de situaçóes em que os guaranis se envolveram após 1801, e podem ser tomados como exemplo da reorientação que ocorreu na historiografia missioneira, cuja preocupação central passou a ser os índios. Especialmente, os registros de batismos contribuem ainda mais com este novo quadro historiográfico, permitindo a recuperação de escolhas individuais e coletivas dos índios, evidenciando a permanência de traços significativos da vida nas Missões entre eles.

Cumpre destacar que a existência destas fontes são, por si mesmas, prova da continuidade da religião entre os guaranis num período ulterior à dissolução do território missioneiro e da expulsão dos jesuítas. Milhares daqueles indígenas levaram seus filhos às pias batismais das capelas e freguesias, cidades embrionárias que iam sendo formadas no sul Brasil nas primeiras décadas do século XIX. Tais eventos ocorreram em áreas que não correspondiam oficialmente ao espaço das Missões, embora outrora tenham integrado as estâncias missioneiras.

Grande parte daquele território, que foi convertido nas primeiras cidades do extremo-sul brasileiro, contaram com população guarani em suas formações. Este é o caso da Capela de Santa Maria, atual município de Santa Maria - Rio Grande do Sul. Aquele espaço integrava a antiga estância da Missão de São Luiz antes da execução do Tratado de Madrid (1750). A presença guarani naquela e em outras localidades do sul do Brasil requer reavaliação da história missioneira, tendo em vista que aqueles indígenas manifestaram certas práticas, como a religião, que remontava à experiência missional dos séculos XVII e XVIII. 
Sendo assim, o objetivo deste artigo consiste em evidenciar como um pequeno grupo de famílias guaranis se estabeleceu entre luso-brasileiros, coexistindo com eles após a tomada das Missões Orientais, em 1801, nas cercanias da Capela de Santa Maria. A hipótese que se apresenta é a de que houve a formação de comunidades guaranis em meio a propriedades rurais luso-brasileiras. $\mathrm{O}$ texto defende que aqueles grupos ainda conservavam traços significativos da religião cristã, a qual era condicionante para a continuidade no tempo dos grupos e/ou das famílias guaranis missioneiras, sobre as quais ainda sabemos pouco no contexto do Brasil do século XIX.

\section{Os Guaranis entre Conflitos}

O Tratado de Madrid (1750) alterou irreversivelmente o mapa humano e geográfico na extremadura sul da América. Uma região ocupada por diversas parcialidades indígenas que já habitavam grandes áreas como Tape ${ }^{4}$ muito antes da chegada dos colonizadores europeus. O Tratado que foi estabelecido entre Espanha e Portugal exigia que guaranis cristianizados abandonassem sete povoados, as Missóes do Uruguai, em benefício dos portugueses. ${ }^{5}$

Em quatro delas ${ }^{6}$, houve resistência armada e uma série de conflitos entre 1753-1756, em que se envolveram guaranis, espanhóis e portugueses. Estes episódios são conhecidos como Guerra Guaranitica, em que houve, como resultado, um grande massacre de indígenas que acabou com 1500 mortos, em 1756. Após a derrota, milhares de guaranis buscaram novas áreas para habitar, o que implicou também adaptaçóes em virtude da ruptura política e social provocada pela guerra (WILDE, 2009).

Aquele momento também coincidiu com o avanço lusitano na América do Sul. Desse processo, originaram-se diversas povoações portuguesas para onde se deslocaram inúmeras famílias guaranis, especialmente para a Freguesia de Santo Ângelo do Rio Pardo (atual município de Rio Pardo - Rio Grande do Sul) para onde se dirigiram cerca de setecentas famílias indígenas (RIBEIRO, 2017). Mais tarde, em 1762, algumas delas foram levadas para o atual município de Gravataí, onde foi fundada a Aldeia dos Anjos (LANGER, 1997; GARCIA, 2007; SIRTORI, 2008).

Como demonstra Karina Melo (2011), um grupo restante integrou a Aldeia de São Nicolau do Rio Pardo. Este aldeamento tornou-se um importante entreposto para guaranis que se deslocavam constantemente pelos antigos territórios que formavam as Missões, entre os quais se incluía toda a região da Fronteira do Rio Pardo, formada por outras localidades como a Freguesia da Cachoeira, Capela de Santa Maria, Capela de Caçapava e Freguesia de Taquari. ${ }^{7}$ Houve grupos que se estabeleceram na Aldeia da Cachoeira (atual município de Cachoeira do Sul), por volta de 1799, e outros na Capela de Santa Maria, por volta de 1804.

Esta última, entretanto, passou a receber levas constantes de população missioneira após a conquista definitiva das missões do Uruguai por luso-brasileiros, em 1801 (RIBEIRO, 2013). Entre essa população em trânsito, havia milicianos, agricultores e peões que buscaram acesso às antigas terras missioneiras que eram paulatinamente ocupadas por colonos luso-brasileiros que as dividiram em pequenas, médias e grandes propriedades. ${ }^{8}$ 


\section{“las tierras naturales desta nacion Guarani”}

Durante a Guerra Guaranítica (1753-1756), os jesuítas foram acusados pelos portugueses de incentivar os guaranis a não aceitarem a transmigração. Como defesa, os jesuítas produziram uma série de relatos sobre o conflito. Num deles, de 1754, há uma descrição geográfica sobre o espaço missioneiro, feita pelo padre Bernardo Nusdorffer, pois julgou necessário fazer uma breve descrição do território em litígio, registrando que:

Los Indígenas como estan, los quales ay se criaron y los han andando continuamente y los andan, assi quando van à los Yerbales y à sus estanciaas. En altura pues del polo austral de $31^{\circ}$ y 30 poco mas ò menos descarga en la mar una junta de aguas de muchos rios, unos vienen de una Serrania grande, que esta ai norte respecto de esta junta de aguas, y se llama la Sierra de la Província del Tape y por ser estos parajes las tierras naturales desta nacion Guarani los llaman los Espanoles indígenas Tapes [...] (MANUSCRITOS DA COLEÇÃO DE ANGELIS, 1969, p. 254.Tomo VII.)

A descrição de Nusdorffer, transposta aos nossos dias, corresponde à região Noroeste, Depressão Central, Serra Geral, estendendo-se ao oeste pelo vale do Jacuí, ao norte pelo vale do Taquari, ao sul até a costa do rio Camaquã e ao leste até a margem ocidental do rio Guaíba. Como se pode notar, a chamada Província do Tape correspondia a uma grande área, que incluía os povoados com suas estâncias e ervais naturais, como representado na figura que segue.?

Figura 1 - Projeção do Território Tape, até 1750, e localização da Capela de Santa Maria

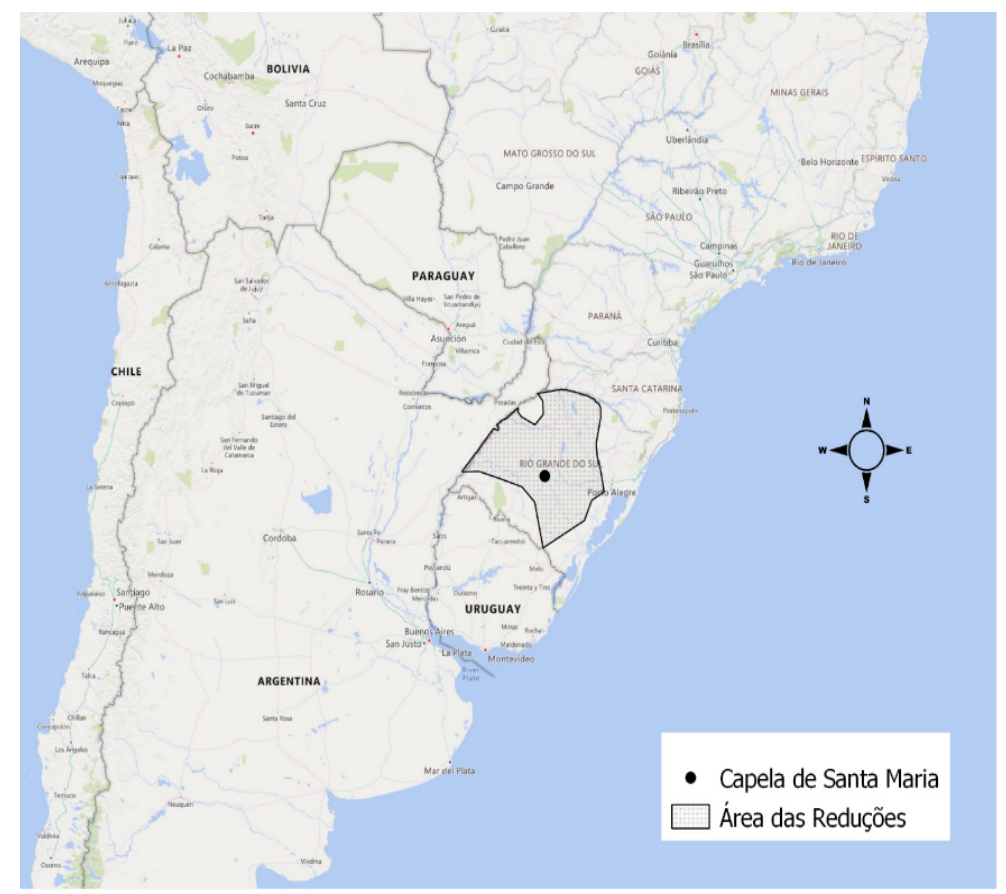

Fonte: Adaptado de Google Earth Pro 2015. Elaborado no software Quantum GIS DESKTOP 3.12.3

A região do Tape, diga-se Missóes do Uruguai, correspondia a praticamente toda a metade norte do Rio Grande do Sul. Naquele espaço, foram instaladas as primeiras reduções do lado 
oriental do rio Uruguai, no início do século XVII. Devido ao ataque dos bandeirantes paulistas, as reduções do Tape foram transferidas para as proximidades do rio Uruguai, em $1638 .{ }^{10}$ Em 1641 , os indígenas derrotaram os bandeirantes na batalha de Mbororé, impondo fim ao apresamento indígena naquela região. Em 1682, indígenas e jesuítas retornaram ao Tape para fundar novas reduções.

O território dito natural dos guaranis assinalado por Nusdorffer, contando as estâncias e os ervais, em litígio entre indígenas e ibéricos, era praticamente o mesmo da época das primeiras reduções. Aquele espaço possuía uma área aproximada de $150.000 \mathrm{~km}^{2}$, repleta de rios, matos, chácaras, estâncias, currais e ervais. ${ }^{11}$ Em 1752, os lusitanos haviam se fixado entre os rios Jacuí e Iobí (Pardo), numa fortificação que ficaria conhecida como Jesus, Maria, José.

O espaço em questão integrava a estância da Missão de São Luiz, que se localizava entre os atuais rios Taquari, costa norte do Jacuí, até o rio Vacacaí. Ao sul, na margem direita do rio Jacuí, a estância de São Luiz limitava-se com a estância do Povo de São Lourenço. Ao oeste, com a estância do Povo de São Miguel. Entre todas elas, estava a estância de São João.

Figura 2 - Estâncias Missioneiras no Vale do Rio Jacuí até 1756

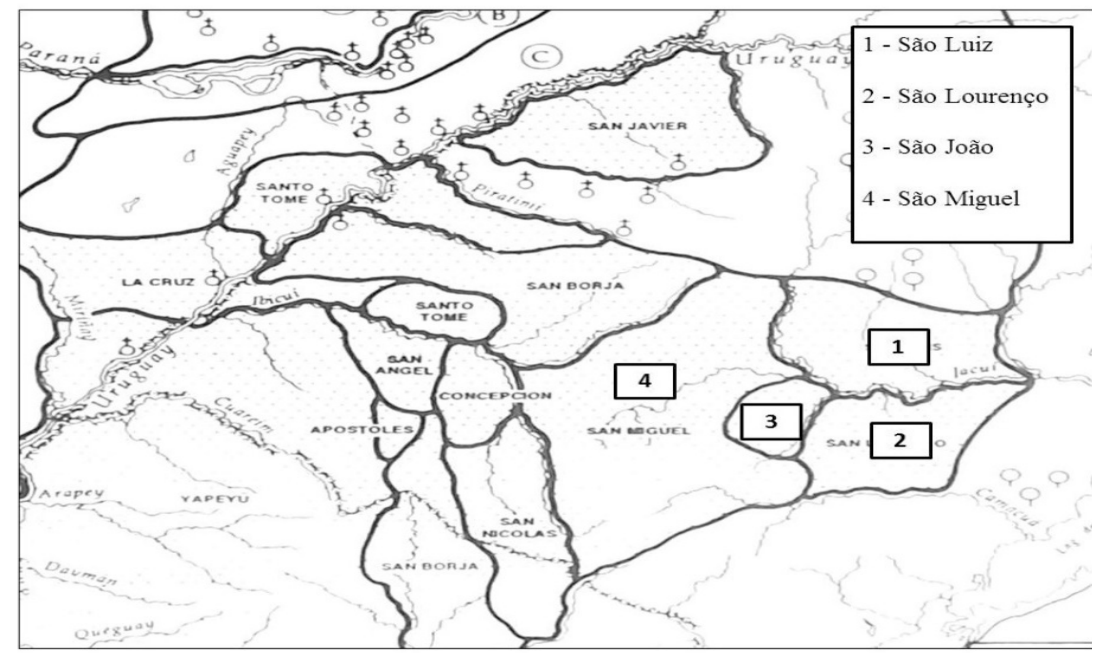

Fonte: Adaptado de Maeder (2010)

Tadeo Xavier Henis, em 1754, registrou que os indígenas da redução de São Luiz haviam percebido que os portugueses edificaram um povoado bastante numeroso de gente e animais com grande número de casas no rio Iobí (HENIS, 1754, p. 9). Os guaranis, reconhecendo os portugueses invasores de seu espaço, acabaram organizando um ataque ao forte, em março de 1754. O exército português, liderado pelo governador Gomes Freire, encontrava-se estacionado na Colônia do Sacramento.

Em julho de 1754, as tropas de Gomes Freire chegaram à fortaleza do Rio Pardo. Temendo os ataques dos guaranis e a possibilidade real de perder a posição no rio Iobí, a marcha em direção a Rio Pardo tinha como objetivo reorganizar o exército para, posteriormente, as tropas rumarem em direção às Missóes. Em setembro daquele ano de 1754, Gomes Freire deu início à marcha, optando pelo trajeto do vale do rio Jacuí. Por desconhecimento da região e, sobretudo, das contingências climáticas, o exército português experimentou as grandes cheias do rio Jacuí (CUNHA, 1853). 
Além da enchente, tiveram que enfrentar o cerco dos indígenas. A cheia do Jacuí impedia que os portugueses se colocassem em formação de batalha, pois as chuvas torrenciais faziam com que os regimentos se socorressem mutuamente na tentativa de salvar mantimentos empregados na logística de guerra, tais como a pólvora. Estes movimentos inviabilizavam qualquer tentativa de atacar os indígenas, devido ao aparato de artilharia ter molhado.

Como aponta Cunha (1853), muitos guaranis dirigiram-se ao general português fazendo diversas ameaças. A enchente colocou o exército português em desvantagem. Em uma carta endereçada ao ministro Sebastião José de Carvalho e Melo (Marquês de Pombal), Gomes Freire descreveu que chegavam, de cada vez, mais e mais guaranis com grande número em cavalaria que cobria mais de um quarto de légua. "Vinha a maior parte dela armada de lanças, em que são destros". ${ }^{12}$

Em desvantagem numérica, sem poder utilizar as armas de fogo, molhadas pela enchente, era arriscado prosseguir a marcha até as reduções. Um cacique de São Miguel foi falar com Gomes Freire alertando que não avançasse em direção às Missões, pois “[...] que aquelas eram suas terras e que se fosse adiante encontraria grande 'poder de índios>” (SÁ; FARIA, 1767 Apud GOLIN, 1999, p. 339). É provável que o tom desafiador daquele guarani tenha contribuído para a reorganização estratégica dos movimentos do exército português.

Naquele mesmo dia, Gomes Freire teria recebido uma resolução do governador de Buenos Aires, José de Andonaegui, para recuar com suas tropas. No dia seguinte, o governador português enviou um chamado aos caciques que comandavam o cerco para que fosse acertada uma resolução de trégua entre os portugueses e os guaranis. O propósito de Gomes Freire era o de conseguir retornar à fortaleza Jesus, Maria, José, no rio Iobí (Pardo).

Compareceram na presença de Gomes Freire indígenas de Santo Ângelo, São Luiz e São Lourenço para firmarem um armistício. Gomes Freire negociou com os caciques a retirada das tropas lusitanas pedindo caminho livre até a fortaleza no rio Iobí, que ficaria conhecida como fortaleza do Rio Pardo. O tratado foi firmado entre o governador português e os caciques, através de juramento sob os "Santos Evangelhos" (HENIS, 1754, p. 35).

Naquela ocasião, as partes acordaram que toda terra existente na margem oriental do rio Guaíba e do Igaí (lagoa dos Patos) ficaria com os portugueses, assim como toda terra na margem ocidental ficaria com os guaranis. Nusdorffer registrou que, logo após as tratativas entre guaranis e portugueses, alguns caciques de São Miguel e São João compareceram diante de Gomes Freire para questioná-lo sobre a situação da fortaleza no rio Iobí.

A fortificação foi construída nas terras pertencentes à estância de São Luiz. Os guaranis procuraram recuperar a área, tentando persuadir o general português. Contudo, Gomes Freire mostrou-se reticente diante da reivindicação dos indígenas. Mas, insistindo, "Replicóle el indígena $\mathrm{q}$ aquellas tierras eran de sus parientes y que en ellas avian estado antiguamente sus primitivos pueblos de S. Christoval, Jesus Maria y S.ta Teresa y S. Luis” (MANUSCRITOS DA COLEÇÃO DE ANGELIS, 1969, p. 281. Tomo VII).

A ocupação portuguesa no rio Jacuí e Iobí (Pardo), onde havia a fortaleza Jesus, Maria, José, que pertencia à estância de São Luiz, localiza-se no atual município de Rio Pardo. Aquele era um espaço missional, reivindicado historicamente pelos guaranis, invadido pelos portugueses, sendo disputado entre estes e os guaranis nos séculos XVII-XVIII. Entretanto, mesmo com a invasão lusitana, não parece ter ocorrido ruptura imediata na ligação histórica entre os guaranis e seu território ancestral. 
O elo entre guaranis e território era, sobretudo, entre eles e seus antepassados cristianizados que povoaram aquele local. Assim, nota-se a relação entre o ator social (indígena) e o espaço habitado, compreendido como lugar de rememoração de experiências pretéritas (cristianização), articuladas como elementos definidores da identidade indígena (RIBEIRO, 2017). Podemos concluir que o território guarani era demarcado por relações de parentesco ancestral, o que, muito provavelmente, orientava decisões individuais e coletivas em seus deslocamentos.

\section{Espaço Missioneiro Sobreposto: os guaranis e a Capela de Santa Maria}

A região da Capela de Santa Maria integrava no século XVII, a antiga redução de São Cosme e Damião, uma das primeiras reduções do Tape (PORTO, 1954; BEUTRÃO, 1979; SANTOS, 2010). Com os ataques dos bandeirantes paulistas, guaranis e jesuítas recuaram à margem direita do rio Uruguai. Retornaram por volta de 1682, introduzindo ali estâncias de gado vacum e novas missões. O Rincão de Santa Maria, assim chamado pelos espanhóis, passou a integrar a estância da Missão de São Miguel, até 1756, tempo da ocupação das Missóes Orientais pelos ibéricos.

Em 1797, militares portugueses responsáveis pela demarcação dos novos limites, estabelecidos pelo Tratado de Santo Ildefonso (1777), fizeram um acampamento no Rincão de Santa Maria. ${ }^{13}$ Ali, foi construído um oratório onde foram realizados alguns sacramentos. Os responsáveis pelas cerimônias eram os padres da Freguesia de São João da Cachoeira, localidade que Santa Maria integrava como distrito até sua emancipação, em 1858.

A partir de 1798, foram iniciados os sacramentais no Acampamento de Santa Maria. Aqueles batizados foram assentados no Livro I de Batismos (1799-1810) da Freguesia da Cachoeira. Santa Maria, por sua vez, foi elevada à Capela Curada em 1812, iniciando suas atividades apenas em 1814, quando assumiu o primeiro sacerdote do povoado. Em fevereiro daquele ano, foi aberto o Livro I de Batismos (1814-1822) da Capela de Santa Maria. Estas fontes possibilitam acompanhar fluxos migratórios dos guaranis missioneiros para aquele lugar.

Estes deslocamentos, ao que tudo indica, intensificavam-se em momentos de conflitos. Como ocorreu em 1756, após a Guerra Guaranitica, a invasão das Missões por luso-brasileiros, em 1801, desencadeou novamente a saída de guaranis dos pueblos em direção à região de Rio Pardo. Um guarani de nome João Antonio Yaichá, capitão dos guaranis, em 1802, solicitava ao governador do Rio Grande de São Pedro, "[...] lhe conceda ao suplicante e seus soldados, e famílias, respectivas retirarem-se para as fronteiras do Rio Pardo.” 14

Aquela atitude do capitão guarani dava-se pela dúvida que tinha em relação ao futuro das Missões. Temia que houvesse a restituição do território missioneiro aos castelhanos e que ele e seus soldados fossem castigados como traidores. Embora o motivo esteja aparentemente explicado, é importante notar a escolha do local para "asilo"; a Fronteira do Rio Pardo, espaço que compunha as estâncias missioneiras.

Um dos muitos destinos da população guarani na Fronteira do Rio Pardo foi o Capela de Santa Maria. A partir de 1804, ocorreram os primeiros batizados de guaranis das missóes, chegando a representarem $25 \%$ (804 registros) de um total de 3026 batizados, até 1834 . Analisando os registros, é possível identificar a procedência geográfica dos pais e das mães guaranis pelos qualificadores 
usados pelos padres, tais como guarani, índio guarani, de nação guarani anotados logo após seus nomes, junto à procedência geográfica de cada um. ${ }^{15}$

Entre o montante de batizados dos guaranis (804 registros), $78 \%$ das mães e $77 \%$ dos pais guaranis eram das Missões. O restante era do Outro Lado do Uruguai ${ }^{16}$, antigas reduções de domínio espanhol. Estes assentos correspondem a $15 \%$ para pais e $18 \%$ para mães. Também se fazem representar nos batismos guaranis naturais de diversas freguesias do Rio Grande de São Pedro, embora em número reduzido, chegando a $7 \%$ para mães e $5 \%$ para os pais.

Os dados são conclusivos sobre a maciça presença missioneira em uma das capelas na fronteira do Rio Pardo. Para Santa Maria, dirigiram-se guaranis de todas as sete povoaçôes missioneiras da margem oriental do rio Uruguai. Distribuindo os registros, podemos visualizar conforme segue:

Gráfico 1 - Distribuição dos Registros Batismais por Povos (Capela de Santa Maria, 1804-1834)

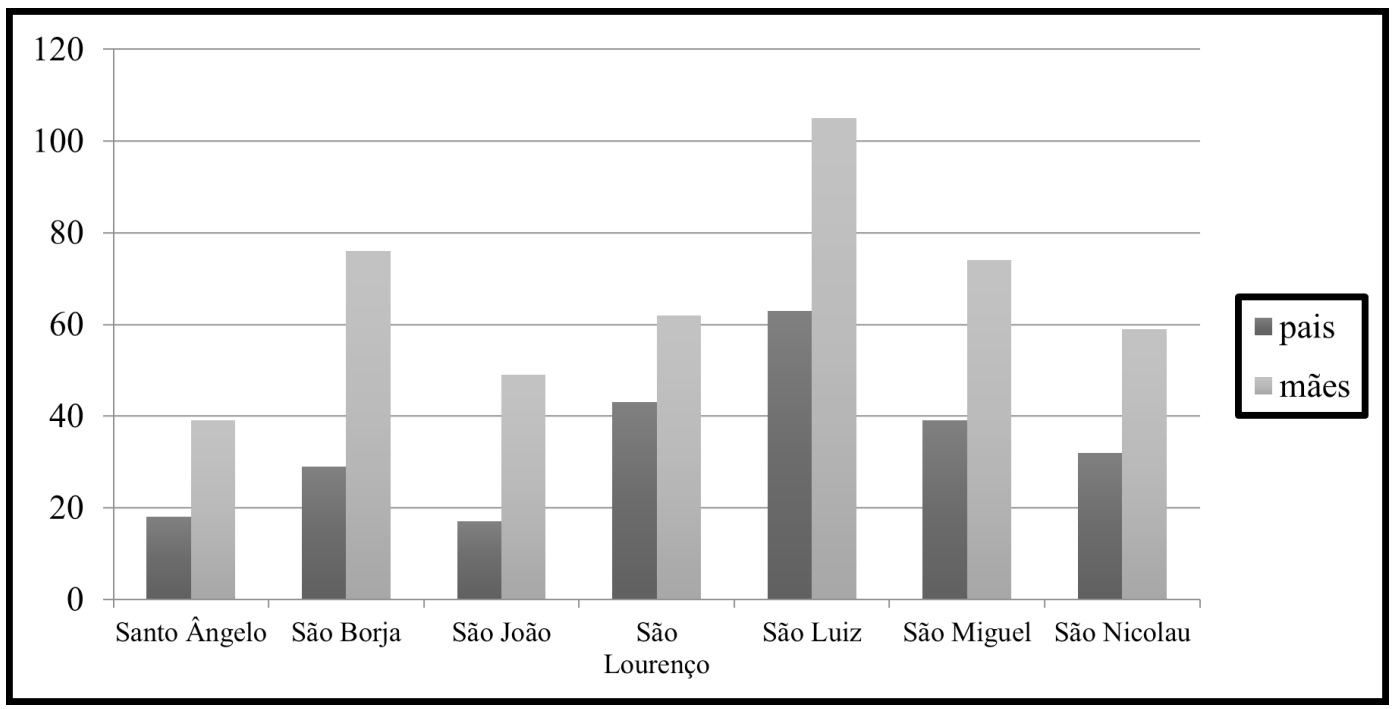

Fonte: Arquivo Diocesano de Cachoeira do Sul (ADCS). Cachoeira do Sul. Livro I de Batismos. Arquivo da Cúria de Santa Maria (ACSM). Livros I e II de Batismos.

É notória a presença guarani das Missões Orientais nos batizados da Capela de Santa Maria. A diferença entre pais e mães também se destaca. Isso ocorreu por causa dos inúmeros registros que não possuem paternidade declarada, sendo a mãe classificada como solteira. Todavia, isto não significa que as mães guaranis não tivessem algum tipo de união sem matrimônio. Considera-se, para efeito, que houve apenas a ocultação do nome de pai por razões diversas, como adultério ou concubinato.

Seja como for, o importante é perceber como os guaranis das Missóes continuaram a procurar o batismo mesmo num período muito além da presença jesuíta. Os batizados de guaranis foram constantes ao longo do período aqui analisado, chegando a uma média de trinta batismos por ano, entre 1804-1834. A partir de 1814, Santa Maria foi elevada de acampamento para capela curada, contando com um padre regular na administração dos sacramentos. 
Gráfico 2 - Ocorrência Anual de Batismos de Crianças Guaranis (Capela de Santa Maria, 1814-1834)

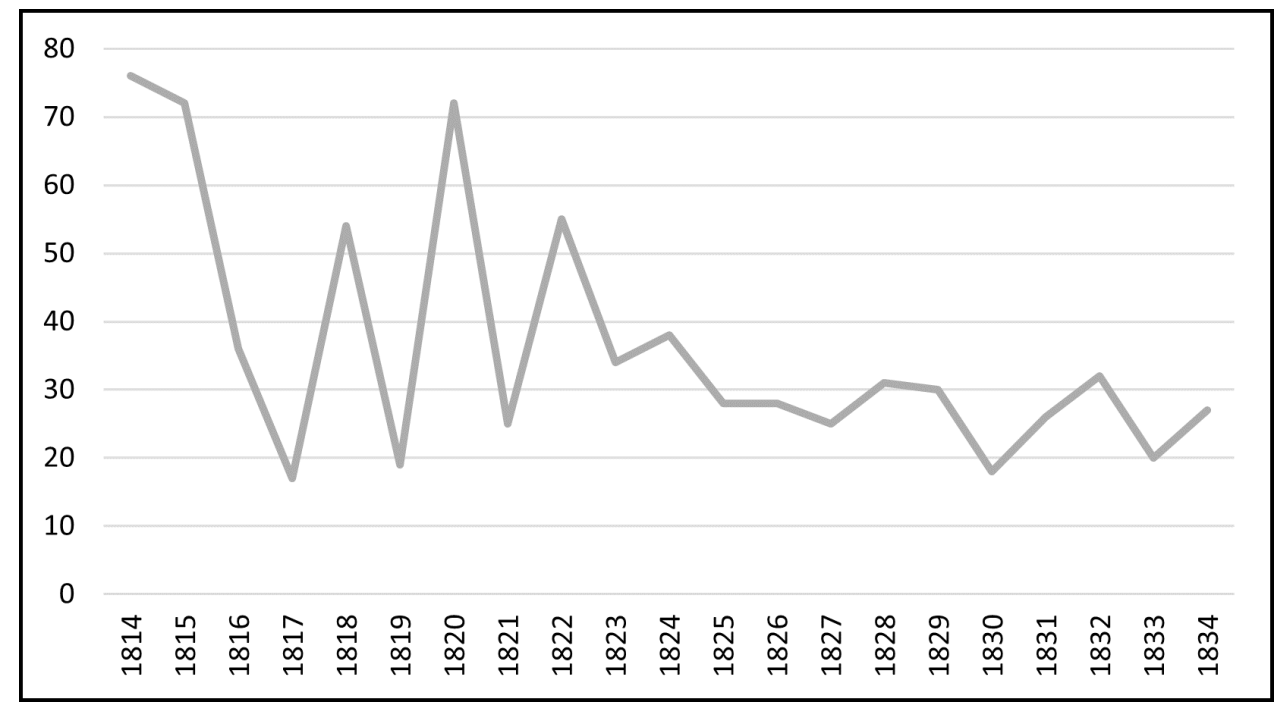

Fonte: Arquivo Diocesano de Cachoeira do Sul (ADCS). Cachoeira do Sul. Livro I de Batismos. Arquivo da Cúria de Santa Maria (ACSM). Livros I e II de Batismos.

A disparidade de batizados nos anos de 1814, 1815 e 1820 pode ter explicaçóes diversas. Pode tratar-se de aumento de nascimentos naqueles anos ou ainda representam a chegada de mais guaranis das Missões. Seja como for, o mais impactante é a procura regular pelo batismo durante todo o primeiro quartel do século XIX. Importante relembrar que Santa Maria integrava as antigas estâncias missioneiras do século XVIII, e isso, de alguma forma, sobrevivia na memória dos guaranis.

O território era crucial para a manutenção do modo de vida guarani. As Missóes representavam o lugar da experiência, da memória e da subsistência, sendo estes elementos básicos da territorialidade desses grupos (RIBEIRO, 2017). Isso pode ser observado após a Guerra Guaranitica, quando muitas dessas famílias buscaram se estabelecer em áreas ancestrais, identificadas pelos indígenas como terra de seus "avós”.

Acreditavam tratar-se de parentes que teriam sido seres sobrenaturais, os primeiros guaranis convertidos ao cristianismo que habitaram o Tape. Seriam os responsáveis pela construção das missões e da organização de todas as áreas adjacentes daqueles povoados (RIBEIRO, 2017). Tratava-se de uma narrativa indígena de cunho mitológico que, de algum modo, orientava parte das açóes sociais, especialmente de uma parcela de população guarani que via a região do Tape como um território ancestral. ${ }^{17}$

A narrativa indígena sobre a origem das Missões mostra que a territorialidade guarani se estabelecia através da presença ancestral. Assim, as fronteiras coloniais, depois fronteiras nacionais, faziam pouco sentido aos guaranis, mesmo que tivessem ciência da dominação e do controle que hispano-crioulos ou luso-brasileiros buscavam alcançar. A série de deslocamentos indígenas pelas localidades que iam sendo fundadas por luso-brasileiros, em finais do século XVIII e início do XIX, possuíam uma referência histórica para os guaranis, já que aquelas áreas outrora formaram as Missões, terra de seus ancestrais (QUARLERI, 2009; RIBEIRO, 2017). 


\section{As Comunidades Guaranis}

Em novembro de 1833, Arsène Isabelle, um viajante francês, anotou que, ao passar por Itaqui, uma localidade brasileira no extremo sul, na fronteira com a Argentina, muitos habitantes viam-se intrigados com sua presença. Isabelle nutria interesse por história natural. Em razão disso, no meio de suas bagagens, carregadas numa carreta tracionada por bois, levava "frioleiras, borboletas, bichinhos, capim, pedrinhas, etc.” fato que estimulou a curiosidade dos moradores daquela localidade (ISABELLE, 2006 [1833], p. 193).

Segundo o viajante "para uns” ele “[...] era um bispo, que vinha restabelecer o reino dos jesuítas nas Missões [...]” (Idem, Ibidem, p. 193). Essa referência nos permite perceber a vivacidade da história missioneira e da presença dos jesuítas na memória dos habitantes do Rio Grande de São Pedro nos idos de 1833. Embora o relato do francês contenha inúmeras inferências antijesuíticas, não foi capaz de conter sua admiração pelos padres.

Este mesmo estranhamento ambíguo foi exposto por seu conterrâneo, August de Saint-Hilaire, cerca de uma década antes. Compartilhava da ideia de que os guaranis haviam sido escravizados pelos jesuítas. Ao mesmo tempo, considerava que os padres haviam os civilizado. Saint-Hilaire reclamou, em sua passagem pelas Missões, que não havia visto nenhum epitáfio ou inscrição que o lembrasse daqueles padres. Porém, entre os guaranis, notou que os “[...] pais continuam a ensinar os filhos a rezar, na língua vulgar, e diariamente têm o cuidado de fazê-los recitar as preces” (SAINT-HILAIRE, 2002, p. 388).

Também notou que "[...] muitos guaranis se lembram de haver ouvido seus pais ou avós falar deles, dizendo que, quando esses religiosos administravam a região, foi o tempo da felicidade” (Idem, Ibidem, p. 388). Este misto de condenação e admiração dos viajantes franceses em relação aos jesuítas lançados à posteridade, convergiam, entretanto, para um tipo de herança dos tempos jesuíticos entre os guaranis visíveis em alguns de seus hábitos. Ela se fazia presente não somente na religiosidade, mas em todo um modo de vida que não foi percebido pelos viajantes.

Os indígenas que passaram pela experiência missional, nos séculos XII e XVIII, praticaram a agricultura mercantil produzindo algodão e erva-mate para exportação, muito embora não tenham abandonado a horticultura (GARAVAGLIA, 1983; CARBONELL, 1992). Trata-se de sociedades seminômades que tiveram seu sistema produtivo modificado pela produção mercantil (MAEDER, 1992). Por essas razões, nas Missóes, parte significativa de homens e mulheres guaranis tinham suas vidas ligadas a atividades no campo, fossem mercantis ou de subsistência.

Nos povoados missioneiros, além dos agricultores havia os peões. Uma lista de ocupações das Missões de 1810, mostra que havia 1658 sujeitos, entre os quais 1372 (83\%) moradores guaranis, $233(14 \%)$ moradores portugueses e $53(3 \%)$ escravos. ${ }^{18}$ Nota-se que a maior parte dos homens era empregada na agricultura, sendo a maioria guarani. Outra parcela importante da mão-de-obra masculina missioneira desenvolvia atividades como peões. ${ }^{19}$

No decorrer da dissolução do mundo missioneiro, os guaranis não deixaram aqueles ofícios de lado. August de Saint-Hilaire, de passagem pela Capela de Santa Maria, em 1820, observou que nas “[...] estâncias dos arredores de Santa Maria há índios desertados das aldeias. Os homens empregam-se como peões e tem consigo toda sua família” (SAINT-HILAIRE, 2002, p. 405). Muito provavelmente, os guaranis que Saint-Hilaire avistou eram remanescentes dos povos missioneiros. Possivelmente, tratava-se de grupos familiares amplos envolvendo não só parentes consanguíneos como também parentes por afinidade, tais como compadres. 
É o que sugerem alguns casos como o da família dos guaranis Felipe Santiago e Maria Gertrudes, naturais do Povo de São Luiz, nas Missões. Juntos, batizaram o pequeno José, filho legítimo de André Guarani e Maria Gertrudes, filho do casal; José era neto dos padrinhos. ${ }^{20}$ Este apadrinhamento ocorrido dentro dessa família sugere que os deslocamentos envolviam um grupo amplo de parentes, cujas decisóes de migrar eram tomadas de forma coletiva.

Felipe Santiago teve 24 afilhados, sendo que, em treze batizados, sua mulher Maria Gertrudes, foi a madrinha. Batizaram, em Santa Maria, quatro filhos. Um dos compadres do casal foi o padre Marcelino Lopes Falcão, um dos sacerdotes da povoação. Felipe Santiago foi testemunha em três cerimônias de matrimônio e ainda foi padrinho de dois escravos africanos pertencentes ao capitão Baltazar Pinto de Aguiar.

Este militar foi o primeiro comandante de Santa Maria, assumindo o cargo em 1810. Naquele mesmo ano, informou a seu superior, o capitão ajudante de ordens Manuel Carneiro da Silva e Fontoura que, por ser um dos primeiros povoadores de Santa Maria, havia ocupado um campo que se achava "devoluto". Em 1816, pediu por sesmaria outro campo que pretendia cultivar. ${ }^{21} \mathrm{O}$ terreno fazia limites com os campos de Bento Gonçalves Chaves que também se tornou seu compadre naquele mesmo ano de $1816 .{ }^{22}$

Podemos concluir que havia uma estreita relação de amizade entre Gonçalves Chaves e o capitão Baltazar. Essa relação mostrou-se, em outros momentos, como atesta o batizado do guarani Manuel, filho de Isabel, solteira índia guarani. Bento Gonçalves Chaves foi o padrinho, e a madrinha foi a filha do capitão Baltazar, dona Luiza Maria de Aguiar. A índia Isabel foi assentada como sendo "agregada do Capitão Balthazar Pinto de Aguiar". ${ }^{23}$

O supracitado capitão batizou doze escravizados. Dois deles, filhos de mães solteiras, tiveram os guaranis Felipe Santiago e sua mulher, Maria Gertrudes, como padrinho e madrinha. São notáveis as relações sociais do capitão com os guaranis, especialmente com um casal que possuía muitos afilhados. Entre as crianças que batizaram estava José, filho de Ramão Grapepó e Maria Rosa, naturais da missão de São Lourenço. Juntos, batizaram outras dez crianças, todas guaranis.

Entre os afilhados de Grapepó e Maria Rosa, havia o menino André, que era filho de Maria Josefa, natural de São Luiz, e de José Antonio, natural de São João, todos guaranis das Missóes, pais da menina Maria. Essa criança, por usa vez, teve como padrinhos Pedro Mateus e Paula Emenegilda, naturais de São Luiz. Batizaram duas crianças, sendo uma delas batizada por Antonio da Costa Pavão e sua mulher, Maria Alves Frilha. Pavão levou à pia batismal de Santa Maria dezessete cativos entre escravizados e escravizadas.

Em 1791, Pavão justificou na região de Santa Maria um rincão no rio Vacacaí por sesmaria, cujo registro diz que ocupava o lugar há quatro anos. ${ }^{24}$ Mais tarde, tornou-se capitão de milícias, também em Santa Maria, adquirindo outras três sesmarias naquele lugar. ${ }^{25}$ É importante frisar, mais uma vez, que todas aquelas terras e suas adjacências eram estâncias missioneiras, sendo Santa Maria, outrora, a estância de São Luiz, pertencente à missão homônima.

É notável também que a maior parte dos guaranis que para lá se deslocaram tinham como naturalidade nos registros batismais o "Povo de São Luiz”, o que mais uma vez reforça o argumento de que aqueles indígenas recorriam a territórios ancestrais. Outro fato importante diz respeito ao peso da territorialidade missioneira na morfologia dos casamentos guaranis, sendo que os cônjuges, pais das crianças batizadas, eram de uma mesma povoação missioneira na ampla maioria dos casos (FARINATTI; RIBEIRO, 2016). 
Porém, no compadrio, notam-se relações mais amplas. Pedro Mateus e Paula Emenegilda, naturais de São Luiz, por exemplo, foram compadres de Ramão Grapepó e Maria Rosa, sua mulher. Essas relações ajudam-nos a criar uma representação gráfica, permitindo a visualização de agregados humanos (cluster) que, por sua vez, nos favorecem a descrição de processos mais gerais. Assim sendo, a sequência de batizados anteriormente descrita pode ser representada conforme segue:

Figura 3 - Representação dos Laços de Compadrio dos Guaranis²6

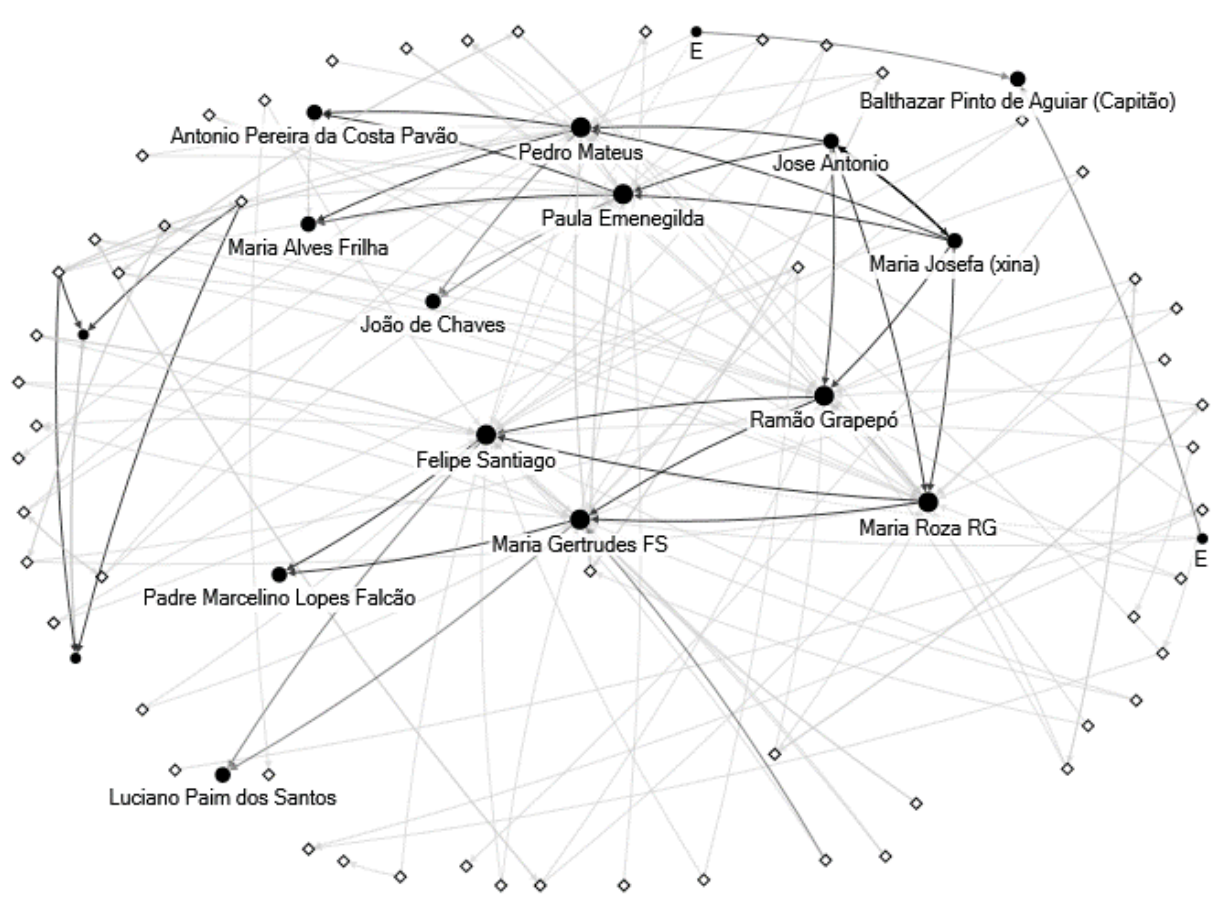

Fonte: ACSM. Livro I e II dos Batismos de Santa Maria - 1814-1845

O que vemos na figura três é um agregado indígena formado por laços de compadrio envolvendo os três casais descritos anteriormente (representados por esferas sólidas maiores). O entrelaçamento, representado pelas setas, entre os casais, sugere a existência de relações sociais entre aqueles indígenas. Ao redor deles, o gráfico mostra uma porção de nós, representados pelos diamantes. Em geral, trata-se de muitas mães solteiras e alguns poucos casados que recorreram a um daqueles três casais como compadres.

Por essa razão, para melhor descrever o gráfico, chamaremos os três casais apadrinhadores de casais receptores, aqueles que receberam muitos afilhados. As setas em destaque mostram, por seu turno, as relaçôes de compadrio estabelecidas por eles quando entregaram seus filhos a outrem como afilhados, onde se vê a presença de indígenas e não indígenas. O importante a ser destacado sobre essas relações de compadrio não é a efetividade do laço, mas perseguir a intenção, a escolha do compadre e da comadre, como um fio condutor para poder remontar a malha relacional de todos e todas guaranis aqui citados.

Vamos observar o cluster agora por outro ângulo, destacando sua morfologia, seu formato de malha, conforme segue: 
Figura 4 - Malha Relacional dos Casais Receptores

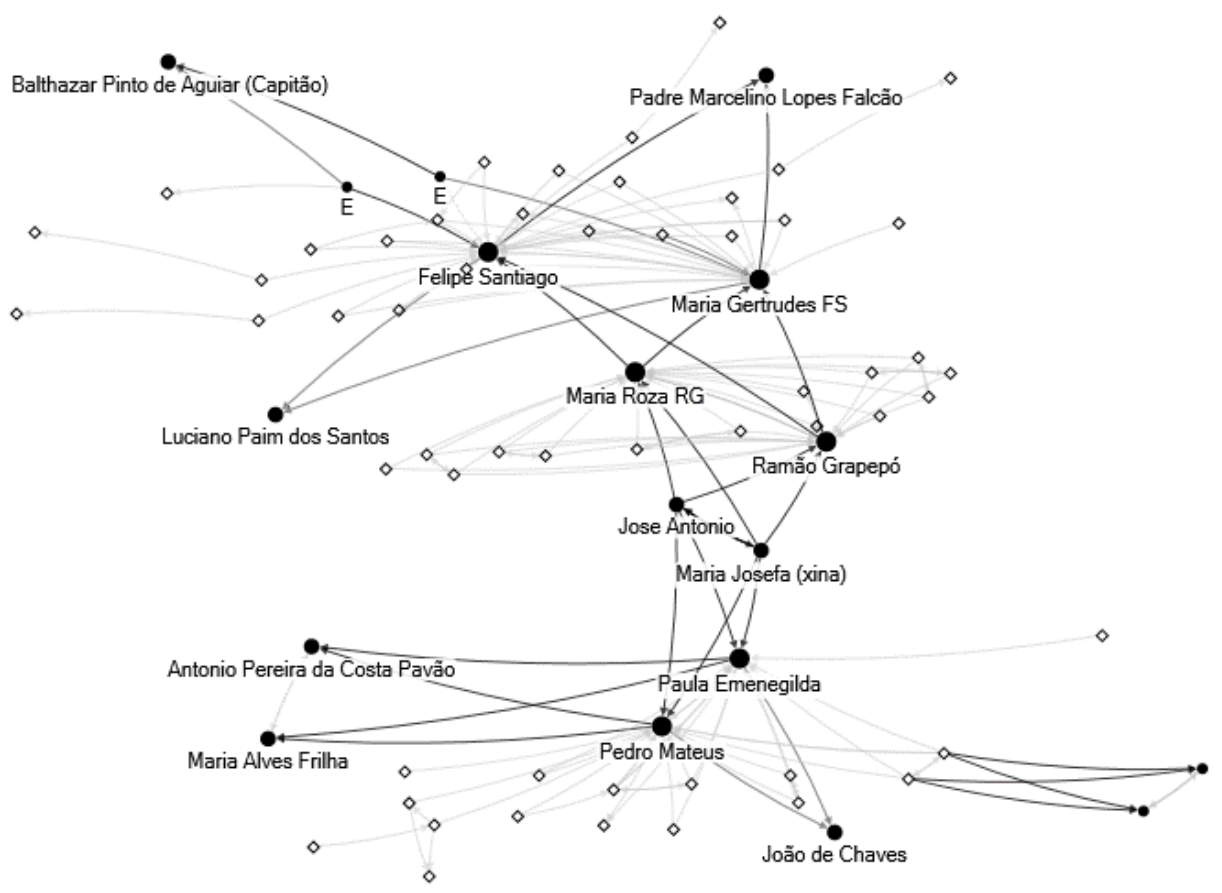

Fonte: ACSM. Livro I e II dos Batismos de Santa Maria - 1814-1845.

Desse ângulo, podemos visualizar a forma da malha relacional dos casais receptores. Vemos que Felipe Santiago e Maria Gertrudes foram compadres de duas mulheres escravizadas (representadas no gráfico pela letra "E”) que pertenciam ao capitão Baltazar. Em sua casa, havia a índia Isabel, sua agregada, sendo compadre dela seu vizinho, Bento Gonçalves Chaves. ${ }^{27}$ Uma de suas escravas foi comadre de um homem escravizado pertencente a Antonio da Costa Pavão. Na figura, vemos que Pavão e sua mulher foram compadres dos guaranis Pedro Mateus e Paula Emenegilda.

Esses indícios sugerem que havia uma relação de vizinhança entre todos, indígenas e não indígenas, que precedia o compadrio. ${ }^{28}$ Pavão possuía uma sesmaria no rio Vacacaí, e o capitão Baltazar era possuidor de campos no "distrito do Vacacaí." 29 As relações de compadrio sugerem que os guaranis retirados das Missóes se estabeleceram em áreas que pertenciam aos povos missioneiros que iam sendo ocupados por luso-brasileiros.

Ao estabelecerem-se naqueles locais que já haviam sido convertidos em propriedades particulares, os guaranis interagiram de modos diversos com os novos ocupantes, sendo o compadrio uma das formas de relacionamento. Naquela conjuntura, é provável que os indígenas vivessem com suas famílias como agregados nas estâncias e nos campos daquelas pessoas e que tenham trocado sua força de trabalho pelo direito de permanecerem naquelas terras.

Saint-Hilaire observou que muitos índios viveram como agregados em pequenas comunidades dentro das estâncias luso-brasileiras após saírem das Missões. $\mathrm{Na}$ estância de um alferes luso-brasileiro, observou que:

Os estancieiros desta região que não têm escravos aproveitam a emigração dos índios para ficar com alguns como peões. Os guaranis são, segundo testemunho geral, muito indicados para esse serviço; montam bem a cavalo, gostam imensamente desse exercício e muitos sabem domar cavalos. (SAINT-HILAIRE, 2002, p. 305-306). 
Parece ser este o caso dos casais receptores e daqueles guaranis que se relacionaram com eles. Possivelmente, todas aquelas famílias formavam uma comunidade indígena que mantinha alguns traços da organização social missioneira. Naturalmente, não se tratava do regime comunitário missioneiro, nem de uma unidade produtiva que gerava excedente. É mais provável que se tratasse de famílias espalhadas por alguns campos e estâncias de particulares, separados por algumas léguas de distância, mas que mantinham laços sociais efetivos.

Segundo Saint-Hilaire, "[...] as palhoças dos índios são muito pequenas e mal arrumadas” (SAINT-HILAIRE, 2002, p. 386). O juízo do viajante permite perceber que, pelo tamanho das casas, aqueles guaranis se organizavam em famílias, nucleadas - pais e filhos -, mas interligadas por parentesco consanguíneo e por afinidade, o que dava a ordem geral de uma família extensa. Na sequência de sua descrição sobre as habitações guaranis, o viajante assenta:

[...] vendo-se nelas apenas espigas de milho suspensas em varais, um pouco de algodão, abóboras, uma rede, alguns farrapos, uma marmita, uma chaleira para mate, alguns bancos e catres de pinho guarnecidos de tiras de couro cruzadas. Este último móvel se encontra em todas as casas dos índios, por mais pobres que sejam. (SAINT-HILAIRE, 2002, p. 386).

Nota-se que a produção da erva-mate e do algodão, gêneros que produziam nas Missóes, ainda permanecia entre eles. Além desses gêneros, ocupavam seus roçados com milho, feijão, batata, abóbora e melancia. Na missão de São Nicolau, em 1820, Saint-Hilaire registrou:

Percorri várias dessas roças em torno da aldeia e encontrei bem cuidadas. As plantas que os índios aí cultivam são, principalmente, milho, várias espécies de feijão, mandioca doce, batatas, abóboras, melancias. Costumam construir pequenas choupanas no meio dessas plantaçóes, onde moram durante a colheita, a fim de impedir os roubos. Notável é que essas roças, que acabo de falar, nunca foram cercadas e não se recorda mais o tempo em que estiveram incultas (Idem, Ibidem, p. 366).

Não contamos com descrições como esta para Santa Maria. Entretanto, é plausível que os guaranis que lá se instalaram tenham desenvolvido produção agrícola semelhante a esta e que tenham construído casas temporárias em meio às plantações. Também podemos notar que, pelo fato da sazonalidade das culturas, os guaranis praticavam deslocamentos populacionais constantes entre campos particulares e até mesmo entre freguesias distintas buscando aproveitar o período mais apropriado das colheitas de seus gêneros. Ainda, conforme aponta Saint-Hilaire, os "[...] índios das Missões, muito pobres para possuírem cavalos, criam burros para sua montaria. Também vi em Santa Maria burros pertencentes a índios” (Idem, Ibidem, p. 407).

Além da montaria, possivelmente empregavam aqueles animais no transporte de sua produção agrícola. É difícil saber como era a divisão do trabalho indígena em Santa Maria, mas as referências em Saint-Hilaire parecem não deixar dúvidas de que os homens se ocupavam de ser peões nas estâncias, ofício que aprenderam nas Missóes. Pelos indícios apontados na obra do viajante referido anteriormente, as mulheres, além de serem agregadas em casas de luso-brasileiros, também se envolviam com a agricultura. Em São João, uma das Missões, o viajante supracitado viu que as plantações, “[...] foram feitas por mulheres e meia dúzia de velhos” (Idem, Ibidem, p. 380).

Para além da divisão do trabalho, a produção agrícola coletiva poderia sugerir um ambiente propício para relaçôes de amizade e reciprocidade entre os guaranis de localidades distintas. As 
relações de compadrio dos casais receptores sugerem que os laços sociais eram estabelecidos com indígenas de várias povoações missioneiras. Izidro, classificado como alferes castelhano, e sua mulher, Valeriana Falcão, por exemplo, eram naturais da missão de São Xavier. Foram compadres de Pedro Mateus e Paula Emenegilda. Felipe Santiago e Maria Gertrudes também batizaram o filho do casal guarani Manuel e Maria, naturais da missão de Apóstolos.

\section{Estrutura da Comunidade Guarani}

Uma das características notáveis nos agregados formados pelos guaranis, as comunidades, é a predominância do gênero feminino. Observa-se não só a forte presença feminina no cluster, conforme a figura que segue:

Figura 5 - Presença Feminina na Malha de Compadrios

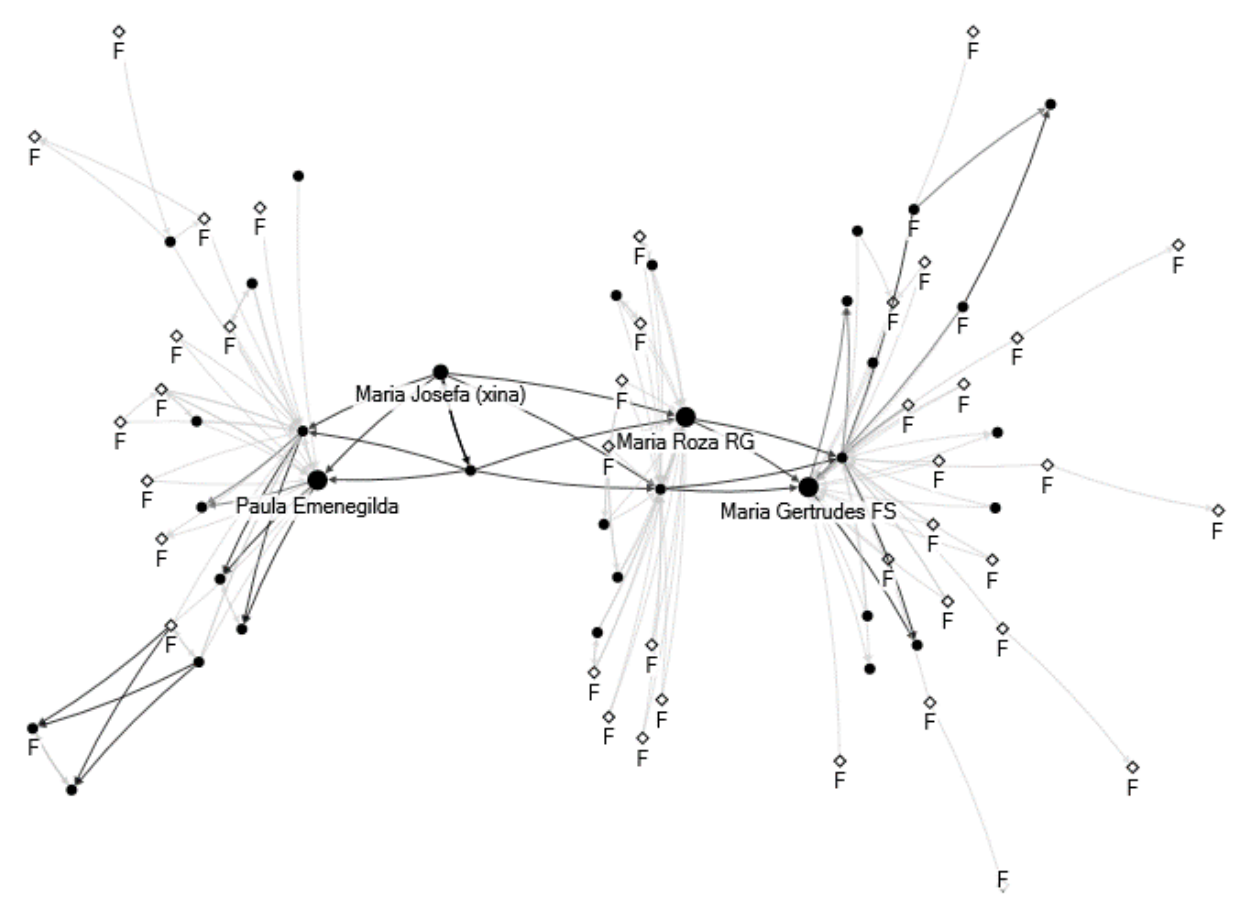

Fonte: ACSM. Livro I e II dos Batismos de Santa Maria - 1814-1845.

A figura cinco dá ênfase às madrinhas indígenas, excetuando-se os homens. Vemos apenas as madrinhas receptoras com suas comadres destacadas pelos nós em que se encontram a letra $\mathrm{F}$ (representando feminino). Calculam-se 78 pessoas neste agregado, sendo 48 delas mulheres. Num total de 38 batizados, elas estiveram juntas de seus cônjuges como madrinhas em 29 sacramentos. Os números e a figura ajudam a perceber que a estrutura básica da malha é formada por mulheres guaranis. ${ }^{30}$

Embora os homens guaranis, como Felipe Santiago, tenham batizado muito mais crianças do que qualquer mulher, em números absolutos, elas concentraram mais afilhados. Esta era uma tendência geral em Santa Maria. Entre as 804 cerimônias batismais, as madrinhas guaranis estiveram presentes em $68 \%$ delas, o que indica uma preferência de gênero nas relaçóes de compadrio dos guaranis (RIBEIRO, 2013). 
A importância social delas pode ser notada analisando a figura 5, pela qual se vê Paula Emenegilda, natural de São Luiz, como comadre de Maria Josefa, também de São Luiz, por sua vez, comadre de Maria Rosa, natural de São Lourenço, por fim, comadre de Maria Gertrudes, natural de São Luiz. O que se vê é um emaranhado de compadrio com protagonismo de mulheres da missão de São Luiz. Aquelas mulheres, madrinhas de muitos afilhados e afilhadas, certamente desempenhavam papel fundamental dentro da comunidade, ajudando a organizar uma espécie de "rede" de solidariedade feminina.

Por falta de maiores dados, o termo rede não é colocado em stricto senso. No entanto, é certo que mulheres guaranis emigradas de diversas missóes passaram a compor um agregado humano, em que suas crianças eram o elo social entre elas e aquelas que já estavam em Santa Maria há mais tempo. É difícil saber se aquelas mulheres tinham algum tipo de relação anterior à saída das Missões, tendo em vista que muitas delas não eram naturais da mesma missão. Seja como for, isso não impediu a formação de uma comunidade em que as relações de compadrio tinham por característica a predominância do gênero feminino.

A descrição de Saint-Hilaire sobre os guaranis vivendo de forma decadente em aldeias compostas por velhos, mulheres e crianças, portanto, é parcialmente correta e, concomitantemente errada. É certa na descrição da população no quesito "mulheres e crianças", mas errada em considerar isso como decadente. Os dados evidenciam que houve, em boa medida, a continuidade de aspectos significativos do modo de vida indígena nas Missóes. Havia uma condição básica para que isso ocorresse.

Embora os homens guaranis desempenhassem papel importante na organização social guarani, já demonstrada por Wilde (2009), como chefes, a continuidade existencial dos guaranis dependia exatamente das mulheres guaranis e de suas crianças. O que Saint-Hilaire via como decadência e atraso era a possibilidade dos guaranis perseverarem como grupo étnico e junto a eles a continuidade da história missioneira. A reprodução biológica aliada a um círculo de criação e amparo às crianças poderia oferecer um ambiente favorável ao modo de vida missioneiro em que as mulheres eram protagonistas.

\section{Conclusão}

O texto procurou mostrar como uma parcela de população guarani continuou a manifestar, no seu modo de organização social, padrões semelhantes ao período missional. São três as características mais evidentes. Primeiro, a continuidade de alguns aspectos da religião, perceptíveis pela representatividade de crianças guaranis batizadas em Santa Maria. Em segundo, a presença guarani em territórios que pertenciam às antigas Missões. Em terceiro, a organização em comunidades por campos e estâncias de luso-brasileiros.

Os dados são contundentes em relação à continuidade da religião cristã entre os guaranis, reforçando o que a historiografia já apontou. Mesmo numa conjuntura ulterior aos jesuítas, período em que se acreditava não haver mais história para os guaranis, pode-se notar a constante procura pelo sacramento do batismo. Embora seja difícil de captar o sentido particular que davam àquele ritual cristão, é provável que buscassem o batismo como prescrição, devido à identificação com seus ancestrais cristianizados nos séculos XVII-XVIII. 
A presença guarani entre luso-brasileiros, nas freguesias, nos campos e nas estâncias, também pode ser explicada através da ligação com seus ancestrais, na busca por espaços habitados por eles no passado. Assim, o território missioneiro, mesmo ocupado pelos luso-brasileiros, ainda era visto pelos guaranis como espaço ancestral e de memória, relacionado do mesmo modo à necessidade de produção e sustento.

A organização familiar, por sua vez, mantinha traços da vida comunitária missioneira, guardadas as devidas reservas. Não se tratava do regime de comunidade em que havia trabalho comunitário para o sustento da população. Entretanto, ao que tudo indica, houve a formação de pequenas comunidades que compartilhavam, em algum grau, semelhanças à vida nas Missóes. Isso porque não se detectam unidades familiares avulsas ou isoladas. O que se pode notar são agregados de guaranis conectados por relaçôes parentais.

Eram comunidades existentes, certamente, entre campos e estâncias de luso-brasileiros, formadas em maior parte por mulheres e crianças guaranis. Não se tratava, porém, de um povoado, mas de uma comunidade estruturada em núcleos parentais, distribuídos por algumas léguas de distância que mantinham vizinhança e laços sociais efetivos. Naquelas comunidades, havia protagonismo feminino, sendo as mulheres as formadoras, possivelmente, de uma rede de amparo e solidariedade que envolvia mães e seus filhos, suas madrinhas e seus afilhados.

Por fim, é digno de nota que a formação daquelas comunidades de índios cristianizados, bem como da presença guarani entre luso-brasileiros no século XIX, lança luz sobre novos entendimentos da história missioneira. Pois nem mesmo a expulsão dos jesuítas, a destruição das igrejas ou a dissolução política do território foi capaz de desvincular uma parcela de população guarani de sua identificação com as Missões. Desse modo, até quando se pode falar em história missioneira?

Para além de tudo, as Missões eram formadas por gentes, índios de várias etnias que, certamente, guardavam um tipo de relação histórica particular com as Missões. Os guaranis de Santa Maria são apenas um entre outros tantos prováveis exemplos.

\section{Referências}

ALDEN, D. The Treaty of Madrid (1750) and the Misions of Paraquaria. Workshop on: Jesuits and Intermediaries in the Early Modern World, 2001.

BAPTISTA, Jean Tiago. Fomes, pestes e guerras-dinâmicas dos povoados missionais em tempos de crise. Porto Alegre. Tese (Doutorado em História). Programa de Pós-Graduação em História. PUCRS, 2007.

BELTRÃO, Romeu. Cronologia Histórica de Santa Maria e do Extinto Município de São Martinho. 2. ed. Canoas: Tipografia Editora La Salle, 1979.

BERTRAND, Michel. Los modos relacionales de las élites hispanoamericanas coloniales: enfoques y posturas. Anuário del IEHS, Tandil, n. 15, p. 61-80, 2000.

CAMARGO, Fernando da S. O malón de 1801: a Guerra das Laranjas e suas implicações na América Meridional. Passo Fundo: Clio Livros, 2001.

CARBONELL, Rafael. Estrategias de desarrollo rural en los pueblos guaraníes (1609-1767). Barcelona: Antoni Bosch, 1992.

CORTESÃO, Jaime. Manuscritos da Coleção de Angelis. Do Tratado de Madrid à Conquista dos Sete Povos (1750-1802). Tomo VII. Rio de Janeiro: Biblioteca Nacional, 1969.

CUNHA, Jacinto Rodrigues da. Diário da Expedição de Gomes Freire de Andrada às missões. Revista do IHGB, Rio de Janeiro, t.16, n. 10, p. 137-258, 1853. Disponível em: http://ihgb.org.br/publicacoes/revista-ihgb/item/ 107710-revista-ihgb-tomo-xvi.html. Acesso em: 07 abr. 2015. 
FARINATTI, Luís Augusto Ebling; RIBEIRO, Max Roberto Pereira. Guaranis nas Capelas da Fronteira: migrações e presença missioneira no Rio Grande de São Pedro (Alegrete e Santa Maria, 1812-1827). In: SANTOS, Júlio Ricardo Quevedo dos. Missões: reflexões e questionamentos. Santa Maria: Editora e Gráfica Caxias, 2016.

FONTELLA, Leandro Goya. Sobre as Ruínas dos Sete Povos: estrutura produtiva, escravidão e distintos modos de trabalho no espaço oriental missioneiro (Vila de São Borja, Rio Grande de São Pedro, c. 1828 - c. 1860). 2013. 282 f. Dissertação (Mestrado em História) - IFCH-Programa de Pós-Graduação em História, UFRGS, Porto Alegre, RS, 2013.

FONTELLA, Leandro Goya; RIBEIRO, Max Roberto Pereira. Grupos e Aglomerações Indígenas no Brasil Meridional: matrimônio e compadrio de guaranis missioneiros em dois contextos distintos (Região das Missões e Fronteira do Rio Pardo, 1814-1824). In: Encontro Escravidão e Liberdade no Brasil Meridional, v. 7, 2015, Curitiba. Anais. Curitiba, 2015. p. 1-15.

FONTELLA, Leandro Goya. As Missões Guaraníticas num contexto de Cultura de Contato: uma interpretação sobre as interações entre sociedades indígenas e euro-americanas (c. 1730 - c. 1830) 2017. 418f. Tese (Doutorado em História) - PPGH-UFRJ, Rio de Janeiro, 2017.

FURLONG, Guillermo. Cartografia Jesuítica del Rio de la Plata. Buenos Aires: Jacobo Peuser, 1936. Digitalizado por Archive Internet (2014). Disponível em: <https://archive.org/stream/cartografiajesuiOOfurl\#page/n41/ mode/2up>. Acesso em: 12 dez. 2019.

GANSON, Barbara. The Guarani under Spanish Rule in the Rio de la Plata. Stanford:Stanford University Press, 2003.

GARAVAGLIA, Juan Carlo. Mercado Interno y Economia Colonial: Tres siglos de historia de la yerba mate. México: Grijalbo, 1983.

GARCIA, Elisa Frühauf. A Integração das Populações Indígenas no Povoados Coloniais do Rio Grande do Sul: legislação, etnicidade e trabalho. 2003. Dissertação (Mestrado em História) - PPGH-UFF, Niterói, RJ, 2003.

GARCIA, Elisa Frühauf. As Diversas Formas de Ser Índio: políticas indígenas e políticas indigenistas no Extremo Sul da América Portuguesa. 2007. 320f. Tese (Doutorado em História) - PPGH, UFRJ, Rio de Janeiro, RJ, 2007.

GIL, Tiago Luís. Infiéis Transgressores: os contrabandistas das fronteiras de Rio Grande e Rio Pardo (17601810). Rio de Janeiro: Arquivo Nacional, 2007.

GOLIN, Tau. A Guerra Guaranítica: como os exércitos de Portugal e Espanha destruíram os Sete Povos dos Jesuítas e índios guaranis no Rio Grande do Sul. Passo Fundo: EDIUPF; Porto Alegre: Ed da UFRGS, 1999.

HANNEMAN, Robert A. Introducción a los métodos del Análises de Redes Sociales. Revista Redes. Barcelona: Universidad Autonoma de Barcelona, p. 1-26, 2000.

HENIS, Tadeo Xavier. Diario histórico de la rebelión y guerra de los pueblos guaranís, situados en la costa oriental del río Uruguay, del año 1754. Versión castellana de la obra escrita en latín por el P. Tadeo Xavier Henis de la Compañía de Jesús, 1754.

ISABELLE, Arsène. Viagem ao Rio da Prata e ao Rio Grande do Sul. Brasília: Senado Federal, 2006.

LANGER, Protásio. A Aldeia Nossa Senhora dos Anjos: a resistência do guarani missioneiro ao processo de dominação do sistema luso. Porto Alegre: EST Edições, 1997.

MAEDER, Ernesto J. A. Misiones del Paraguay: conflicto y disolución de la sociedad guaraní (1768-1850). Madri: MAPFRE, 1992.

MAEDER, Ernesto J. A; GUITÉRREZ, Ramón. Atlas territorial y urbano de las misiones jesuíticas de guaraníes: Argentina, Paraguay y Brasil = Atlas territorial e urbano das reduções jesuíticas dos guaranis: Argentina, Paraguay e Brasil. Junta de Andalucía. Consejería de Cultura, Sevilla, 2010. p. 07.

MAURER, Rodrigo Ferreira. Do um que não é sete: o caso da antiga redução de San Francisco de Borja e a dinâmica da diferença. 2011. Dissertação (Mestrado em História). PPGH/UPF, RS, Passo Fundo, 2011.

MELIĀ, Bartomeu. El Guaraní Conquistado y Reduzido: ensayos de etnohistoria. Asunsión: CEADUC, 1988.

MELO, Karina Moreira Ribeiro da Silva e. A Aldeia de São Nicolau do Rio Pardo: histórias vividas por índios guaranis (séculos XVIII-XIX). 2011. Dissertação (Mestrado em História). Programa de Pós-Graduação em História, UFRGS, Porto Alegre, RS, 2011.

MELO, Karina Moreira Ribeiro da Silva e. Histórias Indígenas em Contextos de Formação dos Estados Argentino, Brasileiro e Uruguaio: charruas, guaranis e minuanos em fronteiras platinas (1801-1818). 2017. Tese (Doutorado em História) - Instituto de Filosofia e Ciências Humanas da Universidade Estadual de Campinas, Unicamp, Campinas, SP, 2017. 
MENZ, Maximiliano. A Integração do Guarani Missioneiro na Sociedade Rio-grandense. 2001. Dissertação (Mestrado em História) - Programa de Pós-Graduação em História, UNISINOS, São Leopoldo, RS, 2001.

NEUMANN, Eduardo. Letra de Índios: cultura escrita, comunicação e memória indígena nas Reduções do Paraguai. São Bernardo do Campo: Nhanduti Editora, 2015.

OSÓRIO, Helen. O Império Português no Sul da América: estancieiros, lavradores e comerciantes. Porto Alegre: Ed. da UFRGS, 2007.

PADRÓN-FAVRE, Oscar. Ocaso de un pueblo indio. Historia del éxodo guaraní-misionero al Uruguay. 2. ed. Durazno: Tierradentro, 2009.

POENITZ, Edgar. La disolución de las misiones:último capítulo. Folia Histórica del Nordeste, v. 6, 1984. p.157-180.

PORTO, Aurélio. História das Missões Orientais do Uruguai. Porto Alegre: Livraria Selbach, 1954.

QUARLERI, Lia. Rebelión y Guerra en las Fronteras del Plata. Guaraníes, Jesuitas e Imperios coloniales. Buenos Aires: Fondo de Cultura Económica, 2009.

RIBEIRO, Max Roberto Pereira. Estratégias Indígenas na Fronteira Meridional: a situação dos guaranis após a conquista lusitana (Rio Grande de São Pedro, 1801-1834). 2013. 150f. Dissertação (Mestrado em História). Programa de Pós-Graduação em História, UFRGS, Porto Alegre, RS, 2013.

RIBEIRO, Max Roberto Pereira. “A terra natural desta Nação Guarani”: Identidade, Memória e Reprodução Social Indígena no Vale do Jacuí (1750-1801). 2017. 269f. Tese (Doutorado em História). Programa de PósGraduação em História, UNISINOS, São Leopoldo, RS, 2018.

SAINT-HILAIRE, August de. Viagem ao Rio Grande do Sul. Brasília: Senado Federal, 2002.

SANTOS, Júlio Ricardo Quevedo dos. As Origens Missioneiras de Santa Maria. In: WEBER, Beatriz Teixeira; RIBEIRO, José Iran (orgs.). Nova História de Santa Maria. Santa Maria: Câmara Municipal de Vereadores de Santa Maria, 2010. p. 107-142.

SARREAL, Julia. Globalization and the Guarani: from Missions to Modernization in the Eighteenh Century. Ph.D. Dissertation. Cambridge: History Departament, Harvard University, 2009.

SERRES, Helenise. As Estâncias Missioneiras na Banda Oriental do Uruguai. 2018. 208f. Tese (Doutorado em História). PPGH, UNISINOS, São Leopoldo, RS, 2018.

SILVA, André Luís Freitas da. Reduções Jesuítico-Guarani: espaço de diversidade étnica. 2011. Dissertação (Mestrado em História). PPGH, UFGD, Dourados, MS, 2011.

SIRTORI, Bruna. Entre a Cruz, a Espada, a Senzala e a Aldeia. Hierarquias sociais em uma área periférica do Antigo Regime. 2008. Dissertação (Mestrado em História Social). Programa de Pós-Graduação em História Social, UFRJ, Rio de Janeiro, RJ, 2008.

SIRTORI, Bruna; GIL, Tiago Luís. Bom dia, padrinho: espaço e parentesco na formação de redes entre cativos nos campos de Vacaria, 1778-1810. Revista Eletrônica de História do Brasil, v. 10, p. 142-160, 2009.

SPOSITO, Fernanda. Santos, Heróis ou Demônios: sobre as relações entre índios, jesuítas e colonizadores na América Meridional (São Paulo e Paraguai / Rio da Prata, séculos XVI-XVII. Tese de doutorado. São Paulo, SP, PPGHiS/USP, 2012.

URQUIJO, José Luis Mariluz. Los guaraníes después de la expulsión de los jesuitas. Estudios Americanos, Sevilha, v. 6, n. 25, p. 323-330, out. 1953.

WILDE, Guillermo. Religión y Poder en las Misiones de Guaraníes. Buenos Aires: SB editorial, 2009.

\section{Notas}

\footnotetext{
${ }^{1}$ Vale destacar o pioneirismo de José Luis Urquijo (1953) que já apontava para continuidade das instituições missioneiras após a expulsão dos jesuítas.

${ }^{2}$ Para maiores informações sobre as consequências do Tratado de Madrid para os índios, ver Tau Golin (1999) e Dauril Alden (2001).

${ }^{3}$ A conquista das Missões Orientais deu-se em decorrência da Guerra das Laranjas na Europa. Sobre isso, recomenda-se a leitura de Fernando Camargo (2001).
} 
${ }^{4}$. Região que se localizava na metade norte do estado do Rio Grande do Sul.

${ }^{5}$ Estas povoações integravam um conjunto de trinta missões que formavam a Província do Paraguai, até 1767, quando da expulsão dos jesuítas das colônias espanholas.

${ }^{6}$ As povoações em questão eram as de Santo Ângelo, São João, São Miguel e São Nicolau. Sobre isso, ver (NEUMANN, 2015).

${ }^{7}$ Conforme Tiago Luis Gil (2007), a partir da segunda metade do século XVIII, os portugueses passaram a chamar a região de Fronteira do Rio Pardo. Os guaranis, porém, chamava o lugar de lobí.

${ }^{8}$ Sobre a ocupação do espaço agrário no Rio Grande do Sul, ver, entre outros (OSÓRIO, 2007). Sobre a conversão do espaço missioneiro, ver (FONTELLA, 2013).

${ }^{9}$ Sobre estâncias missioneiras, ver estudo de Helenise Serres (2018).

${ }^{10}$ Sobre bandeirantismo na América Meridional, ver pesquisa recente de Fernanda Sposito (2012).

${ }^{11}$ Esta estimativa foi gerada a partir de Furlong (1936) e Maeder (2010, p. 7) com auxílio do cálculo de área feito no Google Earth.

${ }^{12}$ Anais da Biblioteca Nacional do Rio de Janeiro, (1928), 1936, v. 50, p. 404-405. Disponível em: <http://objdigital.bn.br/ acervo_digital/anais/anais_050_1928.pdf>. Acesso em: 31 out. 2015.

${ }^{13}$ Tratado que, em suma, restituía as cláusulas do Tratado de Madrid.

${ }^{14}$ Arquivo Histórico do Rio Grande do Sul. Fundo Autoridades Militares. Joaquim Felix da Fonseca. Agosto de 1802 , maço 3.

${ }^{15}$ Embora se saiba da diversidade étnica que existia nas Missões já apontada por Jean Baptista (2007), Wilde (2009) e André Silva (2011), ao que tudo indica, os registros de batismos da Capela de Santa Maria parecem abarcar apenas a população guarani, sem evidência de outros grupos étnicos.

${ }^{16}$ Referência usada pelos padres às missões setentrionais, localizadas além da margem direita do rio Uruguai.

${ }_{17}$ Seria um pequeno grupo guarani unido por relações de parentesco, organizado como um grupo étnico.

${ }^{18}$ Arquivo Histórico do Rio Grande do Sul. Fundo Autoridades Militares. Francisco das Chagas Santos. Dezembro de 1810, maço 16.

${ }^{19}$ Havia também tecelões, carpinteiros, oleiros entre outros.

${ }^{20}$ Fonte: ACSM. Livro II dos Batismos de Santa Maria, 1829, folha 119v.

${ }^{21}$ Fonte: AHRS. Fundo Sesmarias. Balthazar Pinto de Aguiar, 1816. Maço 73.

${ }^{22}$ Fonte: ACSM. Livro II dos Batismos de Santa Maria, 1829, folha 76v.

${ }^{23}$ Fonte: ACSM. Livro II dos Batismos de Santa Maria, 1829, folha 32v.

${ }^{24}$ AHRG. Fundo Sesmaria. Antonio da Costa Pavão. 1791. Maço 3.

${ }^{25}$ AHRS. Fundo Requerimentos. Capitão de Milícias Antônio da Costa Pavão, 1809; 1812;1813; maço 8.

${ }^{26}$ As relações de compadrio foram reconstituídas no software NodeXL Basic, desenvolvido pela Social Media. Trata-se de uma extensão para Excel, open source, criada para análise de redes sociais. A técnica empregada pode ser vista em Fontella e Ribeiro (2015).

${ }^{27}$ Arquivo Diocesano de Cachoeira do Sul. Cachoeira do Sul. Livro I dos escravos, folha 56. 1813.

${ }^{28}$ Estes dados confirmam o que já postularam Gil e Sirtori (2009) sobre a relação entre compadrio e vizinhança.

${ }^{29}$ AHRS. Fundo Requerimentos. Auta Angélica de Aguiar. Maço 24. 1819.

${ }^{30}$ Este é o sentido da análise da morfologia da “rede” referida por Bertrand (2000). A forma do gráfico, sua estrutura mais geral.

Submetido em: 10 de janeiro de 2020

Aprovado em: 05 de maio de 2020 